The Rhetoric of Immediacy 



\title{
The Rhetoric of Immediacy
}

A Cultural Critique of Chan/Zen Buddhism

\author{
BERNARD FAURE
}


Copyright (C) I99 I by Princeton University Press

Published by Princeton University Press, 4 I William Street,

Princeton, New Jersey o8540

In the United Kingdom: Princeton University Press,

Chichester, West Sussex

All Rights Reserved

Library of Congress Cataloging-in-Publication Data

Faure, Bernard.

The rhetoric of immediacy : a cultural critique of Chan/Zen Buddhism / Bernard Faure.

p. $\mathrm{cm}$.

Includes bibliographical references and index.

ISBN 0-691-07374-0 (CL)

ISBN 0-69I-02963-6 (PBK)

I. Zen Buddhism. I. Title.

BQ9265.4.F38 I99I

294.3'927-dc20 91-11746

Publication of this book has been aided by grants from the Suntory Foundation and the Japan Foundation

This book has been composed in Linotron Bembo

Princeton University Press books are printed on acid-free paper and meet the guidelincs for permanence and durability of the Committee on Production Guidelines for Book Longevity of the Council on Library Resources

First Princeton Paperback printing, with corrections, 1994

Printed in the United States of America

I0 $\quad 9 \quad 8 \quad 8 \quad 7 \quad 6 \quad 5 \quad 4 \quad 3$ 
To Dominique, Adèle, and Gaëlle 
